\title{
KEBERHASILAN IMPLEMENTASI PERATURAN PEMERINTAH NOMOR 71 TAHUN 2010 TENTANG STANDAR AKUNTANSI PEMERINTAHAN BERBASIS AKRUAL
}

\author{
MUHAMMAD RAMLI) $^{1)}$, OKKY AFRIWAN ${ }^{2)}$, BUDIARTO ${ }^{3)}$ \\ ${ }^{1,3)}$ Sekolah Tinggi Manajemen Informatika Komputer Mataram \\ ${ }^{2)}$ Akademi Sekretari dan Manajemen Mataram \\ e-mail : ${ }^{1)}$ semangatliee@gmail.com, ${ }^{2)}$ afriwan@gmail.com, ${ }^{3)}$ budiarto5787@gmail.com,
}

\begin{abstract}
ABSTRAK
Penelitian ini bertujuan untuk mengetahui faktor-faktor yang berperan dalam keberhasilan implementasi Peraturan Pemerintah Nomor 71 Tahun 2010 tentang Standar Akuntansi Pemerintahan Berbasis Akrual. Jenis penelitian ini merupakan penelitian kuantitatif dengan metode analisis regresi terhadap faktor regulasi, SDM, komitmen, perangkat pendukung, dan pelatihan yang relevan yang diduga akan mempengaruhi keberhasilan implementasi Peraturan Pemerintah Nomor 71 Tahun 2010 tentang Standar Akuntansi Pemerintahan Berbasis Akrual. Populasi penelitian adalah pengelola keuangan daerah pada 33 Organisasi Perangkat Daerah (OPD)/Satuan Kerja Perangkat Daerah (SKPD) di lingkungan Pemerintah Kota Mataram yaitu Kepala OPD/SKPD dan/atau Pejabat Penatausahaan Keuangan (PPK), Bendahara, dan Staf Perencanaan. Sampel penelitian dipilih dengan metode purposive sampling sebanyak 91 responden dari 99 responden yang diberikan kuesioner. Hasil penelitian menunjukkan bahwa secara parsial kualitas SDM dan pelatihan memiliki hubungan yang signifkan, sedangkan regulasi, komitmen, dan perangkat pendukung tidak memiliki hubungan yang signifikan terhadap keberhasilan pemda dalam implementasi PP 71/2010. Dan berdasarkan analisis simultan menunjukkan bahwa terdapat pengaruh hubungan antara regulasi, sdm, komitmen, perangkat pendukung, dan pelatihan terhadap keberhasilan pemda dalam implementasi PP 71/2010.
\end{abstract}

Kata kunci: Implementasi, PP 71 Tahun 2010, regulasi, SDM, komitmen, perangkat pendukung, pelatihan

\begin{abstract}
This study aims to determine the factors that play a role in the successful implementation of Government Regulation Number 71 of 2010 concerning Accrual Based Government Accounting Standards. This type of research is a quantitative research with a regression analysis method to the factors of regulation, $H R$, commitment, supporting tools, and relevant training which are thought to influence the successful implementation of Government Regulation No.71 of 2010 concerning Accrual Based Government Accounting Standards. The research population is the regional financial manager in 33 Regional Apparatus Organizations/Regional Apparatus Work Units within the Mataram City Government, namely the Head of the OPD/SKPD and/or Financial Administration Officials, Treasurers and Planning Staff. The research sample is selected by using the purposive sampling method with 91 respondents out of 99 respondents who are given questionnaires. The results showed that partially the quality of human resources and training have a significant relationship, while regulations, commitments, and supporting instruments do not have a significant relationship to the success of the local government in implementing PP71/2010. And based on simultaneous analysis shows that there is an influence of the relationship between regulations, human resources, commitments, supporting tools, and training on the success of local governments in the implementation of PP71/2010.
\end{abstract}

Keywords: Implementation PP 71/2010, regulation, human resources, commitment, supporting elements, training 


\section{PENDAHULUAN}

\section{Latar Belakang}

Pengelolaan keuangan daerah, sesuai Peraturan Pemerintah Nomor 58 Tahun 2005 tentang Pengelolaan Keuangan Daerah, adalah keseluruhan kegiatan yang meliputi perencanaan, pelaksanaan, penatausahaan, pelaporan, pertanggung-jawaban dan pengawasan keuangan daerah. Selanjutnya, dalam Undang-Undang (UU) Nomor 23 Tahun 2014 tentang Pemerintahan Daerah - sebagai pengganti dari UU 32/2004 tentang Pemerintah Daerah, pasal 280 ayat (2) menyatakan antara lain bahwa kewajiban penyelenggara Pemerintah Daerah dalam pengelolaan keuangan daerah adalah mengelola dana secara efektif, efisien, transparan, dan akuntabel. Pedoman dan pelaksanaan pengelolaan keuangan daerah - sebagai subsistem pengelolaan keuangan negara - mengacu pada Peraturan Pemerintah Nomor 71 Tahun 2010 selanjutnya disebut PP 71/2010 - tentang Standar Akuntansi Pemerintahan (SAP) Berbasis Akrual dan implementasi PP 71/2010 oleh pemerintah daerah ditetapkan dengan Peraturan Menteri Dalam Negeri Nomor 64 Tahun 2013 tentang Penerapan SAP Berbasis Akrual pada Pemerintah Daerah.

Keberhasilan implementasi PP 71/2010 tentang Standar Akuntansi Pemerintahan Berbasis Akrual oleh pemerintah daerah yang diwujudkan dengan pengelolaan keuangan daerah sesuai dengan PP 71/2010 tersebut, dapat dipengaruhi oleh beberapa faktor. Hasil penelitian Araujo dalam Jorge et al. (2007) bahwa tradisi birokrasi dan perlawanan terhadap perubahan dan fokus pada proses input, telah menghambat keberhasilan reformasi akuntansi (akrual), sedangkan penelitian Mulyani (2018) menunjukkan bahwa regulasi yang telah dikembangkan sebelumnya cenderung kontradiktif dengan adanya regulasi yang baru. Mengenai faktor SDM menurut hasil penelitian Adirianto (2017) dan Arih (2017) bahwa kualitas SDM berpengaruh signifikan dengan arah yang positif terhadap implementasi SAP Berbasis Akrual, sementara itu hasil penelitian Hasri (2017) bahwa kompetensi SDM tidak berpengaruh terhadap keberhasilan implementasi SAP berbasis akrual. Mengenai komitmen, hasil penelitian Kurniawati et al (2017), Mulyani et al (2018), dan Kristiawati (2015) bahwa komitmen organisasi berhubungan positif dengan keberhasilan implementasi sistem akuntansi berbasis akrual. Faktor perangkat pendukung menurut hasil penelitian Arih (2017), Kurniawati (2017), dan Azman (2015) bahwa perangkat pendukung berhubungan positif dengan keberhasilan implementasi sistem akuntansi berbasis akrual, sedangkan hasil penelitian Lamonisi (2016) mengungkapkan bahwa dukungan profesional dan pelatihan staf akuntansi merupakan variabel penentu yang penting pada tahun pertama pelaksanaan reformasi akuntansi pemerintahan.

Selanjutnya, atas hasil penelitian terdahulu tersebut peneliti menggunakan faktor-faktor regulasi, SDM, komitmen, perangkat pendukung, dan adanya pelatihan sebagai faktor-faktor yang diduga akan mempengaruhi keberhasilan pemerintah daerah dalam implementasi PP 71/2010 tentang SAP Berbasis Akrual. Hasil pengamatan awal terhadap pelaksanaan pengelolaan keuangan daerah, yang diindikasikan dengan hasil opini Badan Pemeriksa Keuangan atas Laporan Keuangan Pemerintah Daerah (LKPD) Kota Mataram yakni Wajar Tanpa Pengecualian (WTP) selama empat tahun terakhir dari 2015 sampai dengan 2018, menunjukkan bahwa pengelolaan keuangan daerah telah dilaksanakan sesuai ketentuan yang berlaku. Selanjutnya, hal ini menjadi dasar pertimbangan untuk melakukan penelitian tentang keberhasilan pengelolaan keuangan daerah sesuai Standar Akuntansi Pemerintahan (SAP) Berbasis Akrual.

\section{Perumusan Masalah}

Apakah ada pengaruh faktor-faktor regulasi, SDM, komitmen, perangkat pendukung, dan pelatihan terhadap keberhasilan Pemerintah Daerah dalam implementasi PP 71/2010 tentang SAP Berbasis Akrual.

\section{Tujuan Penelitian}

Penelitian ini bertujuan untuk mengetahui faktor-faktor yang berperan dalam keberhasilan implementasi Peraturan Pemerintah Nomor 71 Tahun 2010 tentang Standar Akuntansi Pemerintahan Berbasis Akrual

\section{METODE PENELITIAN}

Populasi dalam penelitian ini adalah seluruh pegawai pengelola keuangan pada 33 Organisasi Perangkat Daerah/Satuan Kerja Perangkat Daerah (OPD/SKPD) di lingkungan Pemerintah Kota Mataram. Responden yang dipilih, dengan metode purposive sampling, adalah pejabat dan/atau aparatur yang bertanggungjawab dalam pengelolaan keuangan daerah di masing-masing OPD yaitu Kepala OPD atau Pejabat Penatausahaan Keuangan (PPK), Bendahara Penerimaan/Pengeluaran, dan Staf Penyusunan Rencana. Jumlah responden direncanakan sebanyak 99 orang, yang masing-masing diberikan kuisioner yang memuat variabel penelitian 
yaitu lima variabel independen yang meliputi regulasi, SDM, komitmen, perangkat pendukung, dan pelatihan; serta satu variabel dependen yaitu keberhasilan Pemerintah Daerah dalam implementasi PP 71/2010 tentang SAP Berbasis Akrual.

Pengukuran variabel independen berdasarkan persepsi responden terhadap variabel dimaksud. Regulasi diukur berdasarkan persepsi responden tentang perubahan suatu peraturan, kepu-tusan dan perundangan yang berkaitan dengan pengelolaan keuangan daerah. SDM diukur berda-sarkan persepsi respon-den tentang kemampuannya dalam melaksanakan tugas yang diberikan, dan komitmen diukur berdasarkan persepsi responden tentang keinginan dan ketidak-inginan mereka dalam melakukan perubahan. Adapun perangkat pendukung dan pelatihan masing-masng diukur berdasarkan persepsi tentang kecukupan perangkat pendukung tersebut dalam membantu tugas mereka, dan persepsi responden tentang manfaat pelatihan dalam melaksanakan tugas yang diberikan. Untuk variabel dependen, yaitu keberhasilan pemerintah daerah dalam Implementasi PP 71/ 2010 tentang SAP Berbasis Akrual diukur berdasarkan persepsi dari responden tentang penyelesaian penyusunan Laporan Keuangan, yang mencakup: Laporan Realisasi Anggaran (LRA), Laporan Perubahan SAL, Neraca, Laporan Operasional (LO), Laporan Arus Kas (LAK), Laporan Perubahan Ekuiitas (LPE), dan Catatan atas Laporan Keuangan (CaLK). Selanjutnya, variabel ini diukur dengan skala likert (Likert scale) untuk mendapatkan data mengenai bobot setiap jawaban yang diberikan oleh responden. Untuk memberikan bobot dari setiap pilihan jawaban yang ada digunakan angka ganjil, untuk mempermudah penentuan mean (Efferin dkk., 2004: 90-91).Dalam penelitian ini digunakan 5 pilihan jawaban dengan skor: 1 = Sangat tidak setuju; 2 = Tidak setuju; $3=$ Netral (bisa setuju bisa juga tidak setuju); $4=$ Setuju; dan 5 = Sangat setuju. Beberapa pertanyaan digunakan pilihan jawaban yang disesuaikan dengan item pertanyaan (Itemized rating scale)

Selanjutnya, dari jawaban kuisioner sebanyak 91 responden dilakukan analisis statistik. Teknik analisis yang digunakan dalam penelitian ini adalah statistik. Sebelumnya atas seluruh pertanyaan/pernyataan yang ada dalam kuisioner dilakukan uji validitas dan reliabilitas. Uji validitas dilakukan dengan melihat nilai $r$ hitung dibandingkan dengan nilai $r$ tabel. Jika $r$ hitung lebih besar dari $r$ tabel, maka item pertanyaan tersebut dinyatakan valid (Sugiyono, 2009: 352-353). Uji reliabilitas masing-masing instrumen, dilakukan dengan menggunakan koefisien cronbach alpha, dan suatu instrumen dikatakan reliabel jika memenuhi nilai cronbach alpha lebih besar dari 0,5 (Sugiyono, 2009: 365). Selanjutnya, dilakukan uji asumsi klasik yang terdiri atas uji normalitas, multikolinearitas, dan heteroskedastisitas; serta dilakukan uji hipotesis dengan menggunakan analisis regresi linier berganda dan uji F. Tujuan uji normalitas adalah untuk mengetahui apakah distribusi sebuah data mengikuti atau mendekati distribusi normal, yaitu distribusi data dengan bentuk lonceng. Data yang baik adalah data yang mempunyai pola seperti distribusi normal (Kuncoro, 2007: 94). Adapun pengujian multikolinieritas dimaksudkan untuk menguji apakah pada model regresi ditemukan adanya korelasi antar variabel independen. Jika korelasi antara dua variabel bebas melebihi 0,8 maka ada masalah multikolinieritas yang serius (Kuncoro, 2007: 98), sedangkan uji heteroskedastisitas dimaksudkan untuk menguji apakah dalam sebuah model regresi, terjadi ketidaksamaan varians dari residual dari satu pengamatan ke pengamatan yang lain. Jika varians dari residual dari suatu pengamatan ke pengamatan lainnya tetap, maka disebut homoskedastisitas, jika varians berbeda, maka disebut heteroskedastisitas.

Berdasarkan hipotesis yang diajukan, maka model penelitian dapat dibuat sebagai berikut:

Keberhasilan Daerah dalam Implementasi PP 71/2010 $=\beta_{0}+\beta_{1}$ Regulasi $+\beta_{2}$ Komitmen $+\beta_{3}$ $\mathrm{SDM}+\beta_{4}$ Perangkat Pendukung $+e$

Pengujian hipotesis ditujukan untuk menguji ada tidaknya pengaruh dari variabel independent secara keseluruhan terhadap varibel dependen. Pengujian hipotesis dengan menggunakan uji $\mathrm{F}$ atau yang biasa disebut dengan Analysis of Varian (ANOVA).

Pengujian dengan membandingkan F-hitung dengan F-tabel dilakukan dengan ketentuan yaitu apabila F-hitung > F-tabel $(\alpha 0,05)$, maka $\mathrm{H}_{\mathrm{o}}$ ditolak (berpengaruh), sementara sebaliknya apabila F-hitung < Ftabel $(\alpha 0,05)$, maka $\mathrm{H}_{\mathrm{o}}$ diterima (tidak berpengaruh). Adapun $\mathrm{F}$ tabel dicari dengan memperhatikan tingkat kepercayaan $(\alpha)$ dan derajat bebas (degree of freedom).

\section{HASIL DAN PEMBAHASAN}

Penelitian yang dilakukan sesuai metode penelitian yang telah diuraikan di depan diperoleh data yang selanjutnya dengan analisis statistik diperoleh hasil penelitian. Data penelitian yang digunakan adalah data primer berupa jawaban responden atas kuesioner yang telah dikirim sebanyak 91 orang dari yang direncanakan sebanyak 99 orang. 
Hipotesis yang akan diuji adalah pengaruh regulasi, SDM, komitmen, perangkat pendukung, dan pelatihan terhadap keberhasilan daerah dalam implementasi PP 71/2010 tentang Standar Akuntansi Pemerintahan Berbasis Akrual. Ringkasan hasil pengujian hipotesis dapat dilihat pada Tabel 1.

Tabel 1. Ringkasan Pengujian Hipotesis

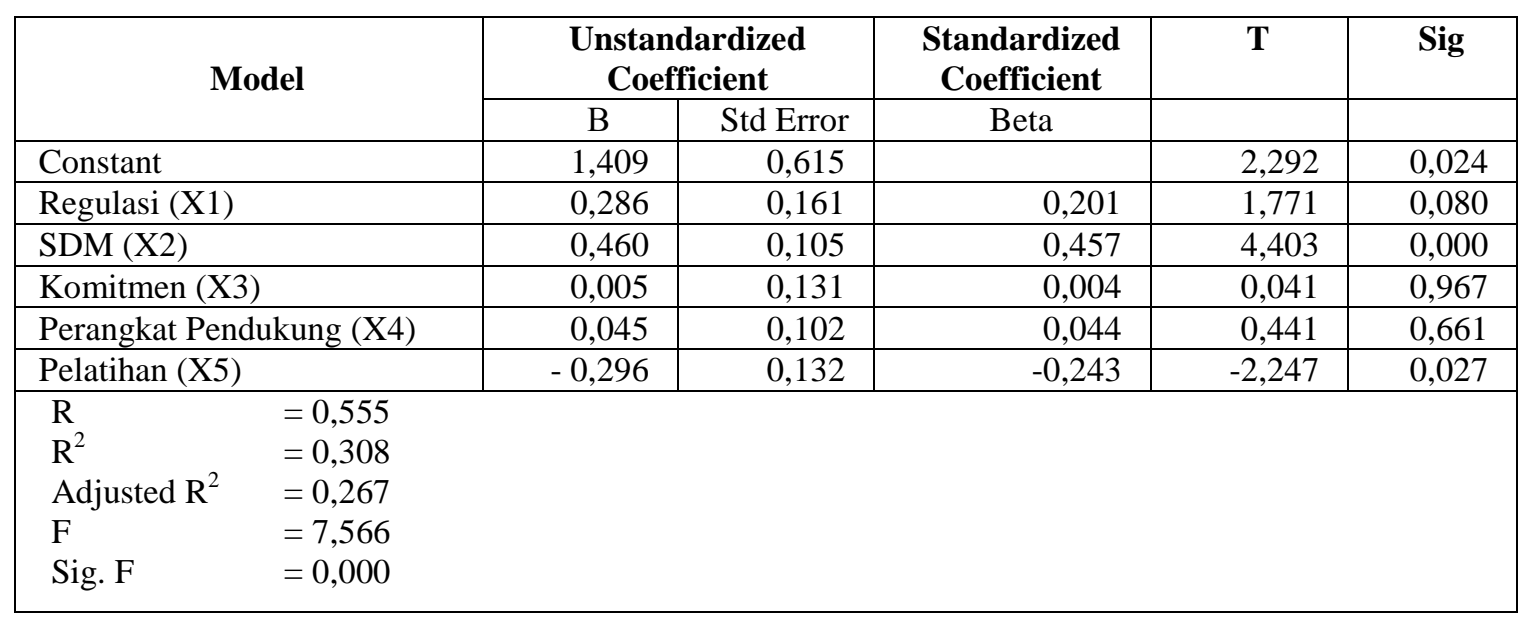

Hasil uji hipotesis yang telah dilakukan tersebut ditunjukkan dalam model penelitian sebagai berikut: $\mathrm{Y}=1,409+0,286 \mathrm{X}_{1}+0,460 \mathrm{X}_{2}+0,005 \mathrm{X}_{3}+0,045 \mathrm{X}_{4}-0,296 \mathrm{X}_{5}+e$

Berdasarkan persamaan di atas, dapat dilihat bahwa koefisien dari variabel regulasi, SDM, komitmen, dan perangkat pendukung masing-masing bertanda positif, yang berarti bahwa keberhasilan daerah dalam imlementasi PP 71/2010 tentang SAP Berbasis Akrual akan meningkat dengan adanya peningkatan dalam hal SDM, komitmen, perangkat pendukung, termasuk adanya perubahan regulasi, dan sebaliknya variabel pelatihan tidak meningkat

Implementasi Peraturan Pemerintah Nomor 71 Tahun 2010 tentang Standar Akuntansi Pemerintahan Berbasis Akrual, untuk meningkatkan akuntabilitas dan transparansi dalam laporan keuangan pemerintah (pemerintah daerah), merupakan tantangan besar bagi pemerintah, dan harus dilakukan secara hati-hati dengan persiapan yang matang dan terstruktur terkait dengan peraturan, sistem, dan SDM. Dalam hal ini pemerintah daerah dituntut untuk dapat mempersiapkan diri dalam pengelolaan keuangan daerah yang sesuai dengan peraturan yang telah ditetapkan tersebut.

Hasil penelitian menunjukkan bahwa keberhasilan pemerintah daerah dalam implementasi Peraturan Pemerintah Nomor 71 Tahun 2010 tentang Standar Akuntansi Pemerintahan Berbasis Akrual, secara simultan terdapat pengaruh hubungan antara regulasi, SDM, komitmen, perangkat pendukung, dan pelatihan terhadap keberhasilan pemda dalam implementasi PP 71/2010, walaupun secara parsial beberapa faktor yaitu regulasi, komitmen dari aparatur pengelolaan keuangan daerah, dan perangkat pendukung tidak memiliki hubungan yang signifikan terhadap keberhasilan Pemerintah Daerah dalam implementasi PP 71/2010 pengelolaan keuangan daerah.

Hasil penelitian menunjukkan bahwa regulasi secara parsial tidak memiliki hubungan yang signifikan terhadap keberhasilan pemerintah daerah dalam implementasi Peraturan Pemerintah Nomor 71 Tahun 2010. Hal ini berbeda dengan pernyataan Bastian (2006) yang menjelaskan bahwa beberapa tantangan dalam implementasi Standar Akuntansi Pemerintahan diantaranya adalah resistensi terhadap perubahan. Hasil penelitian juga berbeda dengan pernyataan Araujo dalam Jorge et al. (2007) dan Mulyani (2018) bahwa tradisi birokrasi dan perlawanan terhadap perubahan dan fokus pada proses input, telah menghambat keberhasilan reformasi akuntansi (akrual). Dan beberapa regulasi yang telah dikembangkan sebelumnya cenderung kontradiktif dan menyebabkan kebingungan di lapangan. Fakta di lapangan menunjukkan bahwa sejak tahun anggaran 2015, dengan demikian kesiapan daerah telah berjalan lima tahun untuk implementasi PP 71/2010, sehingga saat ini regulasi tidak berpengaruh dalam implementasi SAP Berbasis Akrual.

Sumberdaya manusia (SDM) sangat berperan dalam penerapan Peraturan Pemerintah Nomor 71 Tahun 2010. Hasil penelitian menunjukkan bahwa SDM memiliki hubungan yang signifikan terhadap keberhasilan pemerintah daerah dalam Implementasi PP 71/2010. Hal ini mendukung hasil penelitian Adirianto (2017) dan Arih (2017) bahwa kualitas SDM berpengaruh signifikan dengan arah yang positif terhadap implementasi SAP Berbasis Akrual; namun berbeda dengan penelitian Hasri (2017) bahwa kompetensi SDM tidak berpengaruh terhadap keberhasilan implementasi SAP berbasis akrual. 
Selain faktor SDM, dukungan yang kuat dari pimpinan merupakan kunci keberhasilan dari suatu perubahan (Bastian et al., 2006: 7). Diundangkannya Peraturan Pemerintah Nomor 71 Tahun 2010 menunjukkan keinginan yang kuat dari pihak pemerintah untuk memperbaiki sistem keuangan negara/daerah, termasuk perbaikan atas akuntansi pemerintahan, yang selanjutnya mewujudkan upaya pemerintah pusat/daerah dalam peningkatan produk akuntansi pemerintahan dalam pencatatan dan pelaporan oleh departemen/lembaga di pemerintah pusat dan dinas/unit untuk pemerintah daerah. Sistem akuntansi pemerintah pusat/daerah disusun dengan mengacu pada Standar Akuntansi Pemerintahan (SAP). Hasil penelitian yang dilakukan menunjukkan bahwa komitmen dari aparatur pengelolaan keuangan daerah secara parsial tidak memiliki hubungan yang signifikan terhadap keberhasilan pemerintah daerah dalam implementasi PP 71/2010. Hal ini berbeda dengan hasil penelitian Kurniawati et al (2017), Mulyani et al (2018), dan Kristiawati (2015) bahwa komitmen organisasi berhubungan positif dengan keberhasilan implementasi sistem akuntansi berbasis akrual. Dengan demikian, keberhasilan implementasi PP71/2010 kiranya perlu didukung faktor-kator lainnya, selain faktor komitmen dari aparatur penyelenggara pengelolaan keuangan daerah.

Adapun mengenai perangkat pendukung dan sistem informasi yang secara parsial tidak memiliki hubungan yang signifkan terhadap keberhasilan pemerintah daerah dalam implementasi PP 71/2010 dan hal ini berbeda dengan hasil penelitian Tikk (2010) bahwa pondasi yang memadai yang diletakkan untuk transisi ke akuntansi akrual secara penuh, dan didukung dengan pengembangan sistem teknologi informasi, menunjukkan keberhasilan implementasi akuntansi akrual pada sektor publik di Estonia. Demikian juga dengan hasil penelitian Arih (2017), Kurniawati (2017), dan Azman (2015) bahwa perangkat pendukung berhubungan positif dengan keberhasilan implementasi sistem akuntansi berbasis akrual. Berdasarkan hasil pengamatan bahwa kuantitas perangkat pendukung terutama software sistem informasi pengelolaan keuangan daerah di Kota Mataram sudah tersedia di masing-masing SKPD, selanjutnya hal ini berdampak pada persepsi responden mengenai perlunya software dalam implementasi PP 71/2010.

Penerapan PP 71/2010 dipengaruhi pula oleh tersedianya SDM yang terlatih khususnya dalam pengelolaan keuangan daerah. Pelatihan yang relevan yang memadai dan berkelanjutan bagi staf akuntansi dapat meningkatkan kemampuan yang dimiliki dalam pengelolaan keuangan daerah yang mengacu pada Standar Akuntansi Pemerintahan (SAP). Bastian (2006) mengungkapkan bahwa penyiapan SDM dalam pengelolaan keuangan daerah diperlukan adanya lembaga diklat untuk membangun atau meningkatkan kompetensi dari aparatur pemerintahan yang bertugas di dalam menyiapkan, menyusun, dan mengaudit laporan keuangan pemerintah. Luder et al. (2003) dalam Christiaens et al. (2007) menunjukkan bahwa pelatihan terhadap staf akuntansi yang berkelanjutan dalam teknik akuntansi dapat diharapkan tingkat kepatuhannya dalam penerapan reformasi akuntansi pemerintahan lebih signifikan.

Hasil penelitian yang dilakukan menunjukkan bahwa adanya pelatihan dalam pengelolaan keuangan daerah memiliki hubungan yang signifikan terhadap keberhasilan pemerintah daerah dalam implementasi PP 71/2010, namun cenderung menurunkan tingkat keberhasilan implementasi PP 71/2010. Hal ini berbeda dengan hasil penelitian Christiaens et al. (2007), dan Lamonisi (2016) yang mengungkapkan bahwa dukungan profesional dan pelatihan staf akuntansi merupakan variabel penentu yang penting pada tahun pertama pelaksanaan reformasi akuntansi pemerintahan dan dapat memberikan pemahaman yang lebih luas kepada pihak pengelola keuangan daerah sesuai SAP Berbasis Akrual. Hasil penelitian yang berbeda tersebut dimungkinkan karena setelah empat tahun implementasi PP71/2010 penyelenggara pengelolaan keuangan daerah sudah kompeten di bidangnya sehingga tidak memerlukan pelatihan.

Selanjutnya dari hasil penelitian secara simultan menunjukkan bahwa terdapat pengaruh hubungan antara regulasi, SDM, komitmen, perangkat pendukung, dan pelatihan secara bersama-sama terhadap keberhasilan pemerintah daerah dalam implementasi PP 71/2010 tentang SAP Berbasis Akrual, dengan tingkat hubungan sebesar $30.80 \%$, sedangkan $69.20 \%$ dijelaskan oleh variabel lain yang tidak diikutsertakan dalam model regresi. Nilai statistik F dapat digunakan untuk menilai goodness of fit suatu model penelitian (Kuncoro, 2007: 81), dan dari uji statistik $\mathrm{F}$ atau tabel ANOVA menunjukkan bahwa regulasi, SDM, komitmen, perangkat pendukung, dan pelatihan yang relevan secara bersama-sama (simultan) berpengaruh terhadap keberhasilan daerah dalam imlementasi PP 71/2010 tentang SAP Berbasis Akrual. 


\section{SIMPULAN DAN SARAN}

\section{Simpulan}

Berdasarkan hasil penelitian, sesuai metode penelitian dan analisis yang dilakukan, dapat disimpulkan bahwa walaupun faktor regulasi, komitmen, dan perangkat pendukung secara parsial tidak memiliki hubungan yang signifikan terhadap keberhasilan implementasi PP 71/2010 tentang SAP Berbasis Akrual, namun secara simultan/bersama-sama faktor-faktor regulasi, SDM, komitmen, perangkat pendukung, dan pelatihan berpengaruh terhadap keberhasilan implementasi PP 71/2010 tentang SAP Berbasis Akrual. Pengaruh faktor SDM adalah yang tertinggi daripada faktor regulasi, komitmen, perangkat pendukung, dan pelatihan yang relevan, dengan nilai terendah pada faktor komitmen. Hal ini menunjukkan bahwa kualitas SDM memegang peranan utama dalam keberhasilan daerah dalam imlementasi PP 71/2010 tentang SAP Berbasis Akrual.

\section{Saran}

Untuk penelitian selanjutnya endaknya memasukkan variabel lain yang diduga turut mempengaruhi keberhasilan daerah dalam imlementasi PP 71/2010 tentang SAP Berbasis Akrual, dan bagi pemerintah daerah lainnya dapat dijadikan acuan dalam pengelolaan keuangan daerah sesuai ketentuan yang berlaku.

\section{DAFTAR PUSTAKA}

Adirianto, M dan I.B. Riharjo, 2017. "Faktor-faktor yang Mempengaruhi Keberhasilan Penerapan Akuntansi Berbasis Akrual pada SKPD Kabupaten Sidoarjo. Jurnal Ilmu dan Riset Akuntansi, Vol. 6, No. 11, November 2017.

Arih, T.N., Sri Rahyu dan Annisa Nurbaiti, 2015. Analisa Faktor-faktor yang Mempengaruhi Implementasi Standar Akuntansi Berbasis Akrual pada Pemerintah Kota Bandung". Jurnal Manajemen Indonesia, Vol. 11, No. 1, April 2017, halaman 67-77.

Azman, T., 2015. Analisis Komitmen Organisasi, Kesiapan Sumber Daya Manusia, Infrastruktur serta Sistem Informasi dalam Menerapkan Standar Akuntansi Berbasis Akrual.. Jurnal Sorot, Vol. 10, No. 1, April 2015, halaman 131-142.

Azhar, 2007. Faktor-faktor Yang Mempengaruhi Keberhasilan Penerapan Permendagri Nomor 13 Tahun 2006 pada Pemerintah Kota Banda Aceh. Tesis S2 Program Pasca Sarjana USU, Medan.

Bastian, I., 2011. Sistem Akuntansi Sektor Publik”. Penerbit Salemba Empat, Jakarta.

Budiarto, 2011. Faktor-faktor Yang Mempengaruhi Keberhasilan Pengelolaan Keuangan Daerah berdasarkan Standar Akuntansi Pemerintahan (Studi pada Pemerintah Kabupaten Lombok Barat). Tesis S2 Program Pasca Sarjana UNRAM, Mataram.

Christiaens, J., V.V. Peteghem. 2007. Governmental Accounting Reform: Evolution of the Implementation in Flemish Municipalities. Financial Accountability \& Management, 23(4), November 2007, 0267-4424.

Christiaens, J., J. Rommel. 2008. "Accrual Accounting Reforms: Only for Businesslike (Part of) Governments". Financial Accountability \& Management, 24(1), February 2008, 0267-4424.

Direktorat Jenderal Perbendaharaan: Akuntansi Berbasis Akrual, Tantangan Besar Pemerintah: http://www.perbendaharaan.go.id/new/index.php?pilih= news\&aksi=lihat\&id=2526

Erlina, O.S. Rambe, dan Rasdianto. 2015. Akuntansi Keuangan Daerah Berbasis Akrual. Penerbit Salemba Empat, Jakarta

Efferin, S., S.H. Darmadji, Y. Tan. 2004. "Metode Penelitian Untuk Akuntansi”. Bayumedia Publishing.

Forum Dosen Akuntansi Sektor Publik, 2006. "Standar Akuntansi Pemerintahan. BPFE, Yogyakarta.

Halim A. et al. 2007, 2007. Sistem Informasi Keuangan Pemerintah Daerah. Akuntansi dan Pengendalian Pengelolaan Keuangan Daerah. UPP STIM YKPN, Yogyakarta.

Halim A.et al, 2007. Urgensi Standar Akuntansi Pemerintahan. Akuntansi dan Pengendalian Pengelolaan Keuangan Daerah. UPP STIM YKPN, Yogyakarta.

Hasri, A., Akram, dan L.Hamdani Husnan. 2017. Determinants of Successful Implementation of Accrual Based Accounting System For Government. International Conference and Call for Papers, Jember, 2017. 
Jorge S.M., J.B.C. Carvalho, and M. J. Fernandes. 2007. Governmental Accounting in Portugal: Why Accrual Basis is a Problem? J.of Public Budgeting, Accounting \& Financial Management, 19 4), 411 446 Winter.

Kristiawati, E. 2015. Faktor-faktor yang Mempengaruhi Keberhasilan Penerapan Akuntansi Berbasis Akrual pada Pemerintahan Daerah Kalimantan Barat". Akuntabilitas, Vol. VIII, No.3, Desember 2015, halaman 171-190.

Kuncoro, M. 2007. "Metode Kuantitatif: Teori dan Aplikasi untuk Bisnis dan Ekonomi. Edisi Ketiga. UPP STIM YKPN, Yogyakarta.

Kurniawati, B., E. Pituringsih, dan A. Rifai. 2017. "Determinants of Successful Implementation of Accrual Based Accounting System in BPS". International Conference and Call for Papers, Jember, 2017, halamam 871-890.

Lamonisi, S. 2016."Analisis Penerapan Standar Akuntansi Berbasis Akrual pada Pemerintah Kota Tomohon". Jurnal Emba, Vol. 4, No.1, Maret 2016, halamam 223-230.

Mardiasmo, 2009. "Akuntansi Sektor Publik". Penerbit ANDI, Yogyakarta.

Mulyani, S., E. Puspitasari, dan Devianti Yunita H., 2018. "Analysis of the Critical Factors in Supporting the Implementation of the Accrual-based Accounting in the Local Government". Review of Integrative Business \& Economics Resarch, Vol. 7, Supplementary Issue 1 185, halamam 183-199.

Nordiawan D., 2009. "Akuntansi Sektor Publik". Penerbit Salemba Empat, Jakarta.

Peraturan Pemerintah Nomor 58 tahun 2005 tentang Pengelolaan Keuangan Daerah.

Peraturan Pemerintah Nomor 71 tahun 2010 tentang Standar Akuntansi Pemerintahan Berbasis Akrual.

Peraturan Menteri Dalam Negeri Nomor 64 tahun 2013 tentang Penerapan Standar Akuntansi Pemerintahan Berbasis Akrual pada Pemerintah Daerah.

Putra, I.W.G.D., Dodik Ariyanto. 2015. Faktor-faktor yang Mempengaruhi Penerapan Standar Akuntansi Pemerintahan Berbasis Akrual. E-Jurnal Akuntansi Universitas Udayana,13.1 (2015), halamam 14-32.

Sugiyono, 2009. Statistika untuk Penelitian. Penerbit Alfabeta, Bandung.

Surat Edaran Menteri Dalam Negeri Nomor SE.900/316/BAKD Tahun 2007 tentang Pedoman Sistem dan Prosedur Penatausahaan dan Akuntansi, Pelaporan, dan Pertanggungjawaban Keuangan Daerah.

Tikk, J. 2010. Accounting Changes in The Public Sector in Estonia. Business: Theory and Practice, 2010, 111): 77-85.

Undang-undang Republik Indonesia Nomor 17 tahun 2003 tentang Keuangan Negara.

Undang-undang Republik Indonesia Nomor 1 tahun 2004 tentang Perbendaharaan Negara.

Undang-undang Republik Indonesia Nomor 32 tahun 2004 tentang Pemerintahan Daerah.

Undang-undang Republik Indonesia Nomor 33 tahun 2004 tentang Perimbangan Keuangan antara Pemerintah Pusa dan Pemerintah Daerah.

Undang-undang Republik Indonesia Nomor 15 tahun 2005 tentang Pemeriksaan Pengelolaan dan Tanggung Jawab Keuangan Negara. 